\title{
The Role of Acetylsalicylic Acid as an Assistant Drug in the Management of Hepatocellular Carcinoma
}

\author{
Hasan ALACAM, Abdulkerim BEDIR, Veli KILINC, Osman SALIS, Sedat GULTEN \\ Ondokuz Mayis University, Faculty of Medicine, Department of Medical Biochemistry, Samsun, Turkey
}

\begin{abstract}
Glucose regulated protein 78 (Grp78) is a chaperon which acts in the protein folding. Cell-surface Grp78 is present on the surface of different type cancer cells. There are evidences that acetylsalicylic acid (ASA) provides advantages when combined with other chemotherapeutic agents in cancer patients. Resistance is an important problem in cancer treatment and etoposide is a drug which develops resistance against itself. Our purpose in this study is to see how the ASA, either used alone or combined with etoposide, affect on the HepG2 cell viability and to investigate the relationship of this viability with the cell-surface Grp78. Thus 12 different groups were assigned. Control group, $0.5 \mu \mathrm{g} / \mathrm{ml}$ etoposide group, 2.5, 5, $10 \mathrm{mM}$ ASA groups, $10 \mathrm{mM}$ 2-deoxyglucose (2-DG) + 0.5 $\mu \mathrm{g} / \mathrm{ml}$ etoposide group and the groups added to this group with 2.5, 5 and $10 \mathrm{mM}$ ASA respectively, $10 \mathrm{mM}$ 2-DG +2.5 mM ASA group, $10 \mathrm{mM}$ 2-DG + 5 mM ASA group, $10 \mathrm{mM}$ 2-DG + 10 mM ASA group. MTT test was applied for the follow up of the viability of the cells. When the viability in etoposite group was \%84.5, the viability in 2-DG+etoposit group was \%75.4. This shows that 2DG decreases the viability of the cells a little. Also, when ASA is applied alone or combined with 2-DG, it caused decrease in the cell viability but this effect was more significant when combined with 2-DG. When etoposide and ASA were combined, the decrease in high-dose viability was more significant. Cell surface Grp78 levels were higher in the group in which 2-DG and ASA were combined each other than the group in which ASA was applied alone. All these results show that cell-surface Grp78 is important for ASA showing its effect. New treatment protocols focused on the cell-surface Grp78 in cancer treatment can be revealed by further studies.
\end{abstract}

Keywords: Grp78, Cell-surface Grp78, HepG2, Etoposide, Acetylsalicylic acid

\section{ÖZET}

Hepatosellüler Karsinoma Tedavisinde Yardımcı bir İlaç Olarak Asetilsalisilik Asit'in Rolü

Glucose regulated protein 78 (Grp78) protein katlanmasında rol oynayan bir şaperondur. Cell-surface Grp78 farklı türde kanser hücrelerinin yüzeyinde bulunmaktadır. Acetylsalicylic acid (ASA)'nın kanser hastalarında kullanımının fayda sağladığına dair kanıtlar vardır. Kanser tedavisinde direnç önemli bir problemdir ve etoposide kendisine direnç gelişen bir ilaçtır. Bizim bu çalışmadaki amacımız etoposide ile kombine olarak ya da tek başına kullanılan ASA'nın HepG2 hücre viabilitesi üzerine nasıl etki ettiğini görmek ve bu canlılığın cell-surface Grp78 ile ilişkisini araştırmaktır. Bu amaçla 12 farklı grup oluşturuldu. Kontrol grubu, 0.5 mg/ml etoposid grubu, 2.5, 5, $10 \mathrm{mM}$ ASA grupları, $10 \mathrm{mM}$ 2-deoxyglucose (2-DG) + $0.5 \mu \mathrm{g} / \mathrm{ml}$ etoposid içeren grup ve bu gruba sırasıyla 2.5, 5 ve $10 \mathrm{mM}$ ASA eklenen gruplar, 10 mM 2-DG +2.5 mM ASA grubu, 10 mM 2-DG + 5 mM ASA grubu, 10 mM 2-DG + 10 mM ASA grubu. Hücrelerin canlılıklarının izlenmesi içinde MTT testi yapıldı. Sadece etoposit verilen grupta canlılk \%84.5 iken, 2-DG+etoposit verilen grupta canlılık \%75.4 kadardı. 2-DG'nin hücreler üzerinde bir miktarda olsa canlılığı azalıtıı̆ını göstermektedir. Ayrıca, ASA, tek başına verildiğinde ya da 2-DG ile kombine edildiğinde hücre viabilitesinde azalmaya neden oldu, ancak 2-DG ile kombine edildiğinde bu etki daha belirgindi. Etoposide ile ASA kombine edildiğinde yüksek dozlarda viabilitedeki azalma daha belirgindi. Cell surface Grp78 düzeyleride 2-DG ile ASA'nın kombine edildiği grupta tek başına ASA verilen gruba göre daha yüksekti. Bütün bu sonuçlar ASA'nın etkisini göstermesinde cell-surface Grp78'in önemli olduğunu göstermektedir. Kanser tedavisinde cell-surface Grp78'in hedef alındığı yeni tedavi protokolleri ileri çalı̧malarla ortaya çıkarıabilir.

Anahtar Kelimeler: Grp78, Cell-surface Grp78, HepG2, Etoposit, Asetilsalisilik asit 


\section{INTRODUCTION}

The glucose regulated protein 78 (Grp78), determined by the increase of the synthesis in the chicken embryo fibroblasts culture processed with glucose free medium in 1977 first, is a chaperon acting in the protein folding in endoplasmic reticulum. ${ }^{1}$ Grp78 is localized in nucleus ${ }^{2}$, mitochondria ${ }^{3}$ and cytoplasm ${ }^{4}$, cell surface (cell-surface Grp78) ${ }^{5}$ and it is so important for the cell to continue living. ${ }^{6.8}$

Cell-surface Grp78 is present on the surface of different cancer cells such as melanoma cell line (Me6652/4), osteosarcoma (SJSA-1) and hepatoma cell line (HepG2). ${ }^{9}$ The interaction of cell-surface Grp78 with different molecules on the cell surface cause the activation of different signal pathways. The interaction of cell-surface Grp78 and $\alpha_{2}$-makroglobulin on prostate cancer cell line 1-LN increase metastasis..$^{10}$ The interaction of cell-surface Grp78 and $\alpha_{2}$-makroglobulin also increase cell proliferation and cell survival. ${ }^{11}$ Cripto1, taking place in the embryological development and tumor progression, increase tumour growth being complexed with cell-surface Grp78. The prevention of the formation of this complex by the antibodies decreases the formation of oncogenical signal formation..$^{12}$ Some molecules connected to cell-surface Grp78, can cause exact opposite effects. For example; when Par-4 and TRAIL (tumor-necrosis factor-related apoptosis-inducing ligand) are connected, it causes activation in extrinsic apoptotic pathways..$^{13}$

Grp78 is present on the surface of proliferated endothelium cells. ${ }^{14}$ When the tumour tissues grow, they need neovascularization in order to provide feeding and oxygenation. On the membrane surface of HUVECs (human umbilical vein endothelial cells) stimulated by VEGF (vascular endothelial growth factor), an increase in Grp78 quantity is seen. ${ }^{15}$

Grp78 interacts with caspase-7 by the courtesy of ATP binding domain in its structure and prevents apoptosis. ATP binding domain has also an ATP hydrolysis effect and the mutation in this domain eliminates the apoptosis preventing effect of Grp78. ${ }^{16}$

Lots of epidemiological and experimental studies are performed regarding to the benefits of acetylsalicylic acid (ASA) used on the cancer patients. ${ }^{17-18}$ Inhibition of potential neoplastic prostoglandins formed by Cyclo-oxygenase 2 (COX2), by ASA provides po- tential protection against cancer. ${ }^{19}$ As an example, the prostaglandin levels in colorectal tumor tissues are high and it is thought that the cyclo-oxygenase (COX) inhibition of ASA or non-steroidal anti-inflammatory (NSAIDs) drugs provides benefit. ${ }^{20-21}$ ASA activates different signal pathways and causes apoptosis..$^{22}$ ASA used in hepatocellular carcinoma (HCC), prevents lung metastasis by decreasing the quantities of intercellular adhesion molecule-1 (ICAM-1) and vascular cell adhesion molecule-1 $(\mathrm{VCAM}-1) .^{23}$

There are various studies in respect of the usefulness of etoposide in HCC treatment. ${ }^{24}$ Etoposide causes apoptosis by interacting with topoisomerase II. ${ }^{25} \mathrm{Al}$ so, by increasing the reactive oxygen species (ROS) quantity, it also causes apoptosis by protein kinase $\mathrm{C}$ delta (PKCס), p38 MAPK and caspase-3 stimulation. ${ }^{26}$

The resistance development in cancer treatment is the most important problem. During the etoposide treatment, resistance can also be seen and the studies are still ongoing for the auxiliary drugs which will provide the elimination of this resistance. Our purpose in this study is to see how the ASA, whether used alone or combined with etoposide, affect on the cell viability and to investigate the relationship of this viability with the cell-surface Grp78.

\section{MATERIALS and METHODS}

Cells and passaging: In our study, the passage 17 HepG2 (human hepatocellular carcinoma) cells were used. The cells are reproduced in a drying oven with $37^{\circ} \mathrm{C}, 5 \% \mathrm{CO} 2$ and $95 \%$ humidity within DMEM medium (Biological Industries, Israel) including $10 \%$ fetal bovine serum (FBS) (Sigma Aldrich, USA), $100 \mathrm{U}$ penicillin/ $0.1 \mathrm{mg}$ streptomycin (Sigma Aldrich, USA), 4 mM L-Glutamine (Biological Industries, Israel) and $1 \mathrm{~g} / \mathrm{L} \mathrm{D}$-glucose. When the cells were $70-80 \%$ confluent, they were passaged.

\section{Determination of the cell quantity in the working} groups: In order to obtain significant data in drug experiments; the initial cell quantity should be selected carefully. Thus, the cell quantity to be used in the experiment was determined by the real time cell analyzer system (xCELLigence RTCA DP, Roche, Germany). A preliminary experiment was prepared and the cells were planted in the wells with different 


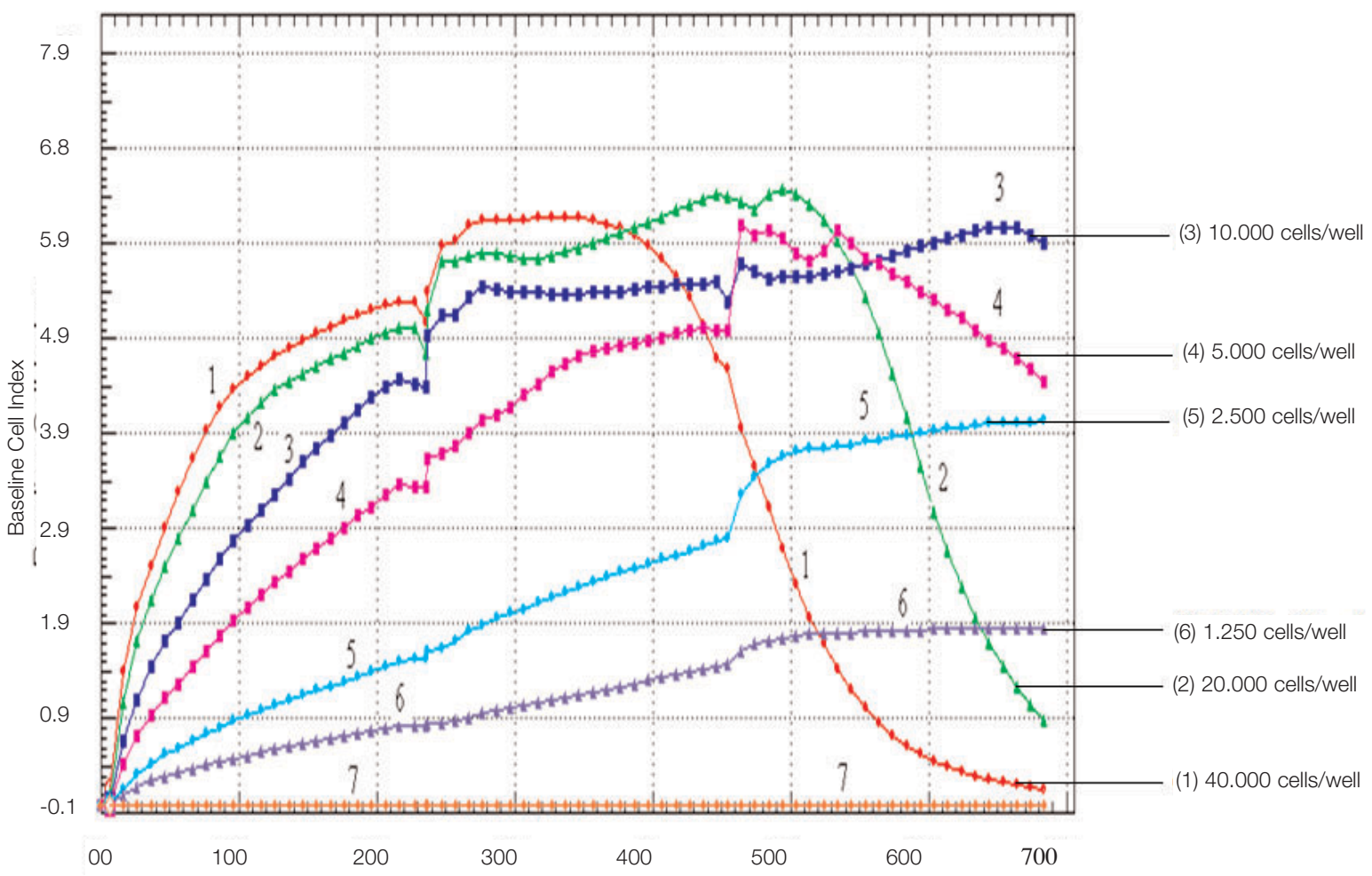

Graphic 1. The growth curves of HepG2 cells in the Real time cell analyzer system. The growth was monitored for 70 hours. (1) 40,000 cells/well, (2) 20,000 cells/well, (3) 10,000 cells/well, (4) 5,000 cells/well, (5) 2500 cells/well, and (6) 1,250 cells/well.

quantities and the growth curves were obtained. Thus, 6 groups with different cell quantities were created: (1) 40,000 cells/well, (2) 20,000 cells/well, (3) 10,000 cells/well, (4) 5,000 cells/well, (5) 2500 cells/well, and (6) 1,250 cells/well. In our study, the cell quantity was determined as 5,000 cells/well and the drugs were applied after the planted cells were reproduced for 24 hours (Graphic 1).

Working groups: In our study, 12 groups were generated. These groups were; (1) control group, (2) $0.5 \mu \mathrm{g} / \mathrm{ml}$ etoposide (Kocak, Turkey) group, (3) 2.5 $\mathrm{mM}$ acetyl salicylic acid (Bayer, Germany) group, (4) $5 \mathrm{mM}$ acetyl salicylic acid group, (5) $10 \mathrm{mM}$ acetyl salicylic acid group, (6) $10 \mathrm{mM}$ 2-deoxyglucose (2-DG) (Sigma Aldrich, USA) and $0.5 \mu \mathrm{g} / \mathrm{ml}$ etoposide group, (7) $10 \mathrm{mM}$ 2-deoxyglucose, $0.5 \mu \mathrm{g} / \mathrm{ml}$ etoposide and $2.5 \mathrm{mM}$ acetyl salicylic acid group, (8) $10 \mathrm{mM}$ 2-deoxyglucose, $0.5 \alpha_{2} \mathrm{~g} / \mathrm{ml}$ etoposide and 5 $\mathrm{mM}$ acetyl salicylic acid group, (9) $10 \mathrm{mM}$ 2-deoxyglucose, $0.5 \alpha_{2} \mathrm{~g} / \mathrm{ml}$ etoposide and $10 \mathrm{mM}$ acetyl salicylic acid group, (10) $10 \mathrm{mM}$ 2-deoxyglucose and $2.5 \mathrm{mM}$ acetyl salicylic acid group, (11) $10 \mathrm{mM}$ 2-deoxyglucose and $5 \mathrm{mM}$ acetyl salicylic acid group, (12) $10 \mathrm{mM}$ 2-deoxyglucose and $10 \mathrm{mM}$ acetyl salicylic acid group.

In 7 of the 12 groups generated in our study, the cells were reproduced in $10 \mathrm{mM}$ 2-DG medium instead of $1 \mathrm{~g} / \mathrm{L}$ D-glucose. The remaining 5 groups are reproduced in $1 \mathrm{~g} / \mathrm{L}$ D-glucose medium. The drugs were applied on the 24th hour after the cells were planted in the real time cell analyzer plates and the growth curves of the cells in every group were followed for 54 hours.

\section{3-(4, 5-dimethylthiazol-2-yl)-2,5 diphenyl tetrazo-} lium bromide (MTT) Assay: MTT test was used to measure the viability of the cells was applied according to the instructions of the manufacturing company (Roche, Germany). The principle of the test is based on converting the yellow colored MTT to purple colored formation compounds by the living cells and measuring the color obtained. In this reaction, NADH and NADPH were used as cofactors. 96- 
well tissue culture plate 5,000 cells/200 $\mu \mathrm{l} /$ well were planted and they were kept waiting for 24 hours in a drying oven with $5 \% \mathrm{CO}_{2} 95 \%$ humidity at $37^{\circ} \mathrm{C}$. After 24 hours, the drugs were applied separately for every group and they were kept in the incubator for 24 hours. Then, the cells were incubated at $37^{\circ} \mathrm{C}$ for 4 hours in $0.58 \mathrm{mg} / \mathrm{ml}$ MTT solution which was prepared in PBS. After incubation, 10\% SDS prepared in $0.01 \mathrm{M} \mathrm{HCl}$ was added and it was kept in a drying oven with $5 \% \mathrm{CO}_{2}$ and $95 \%$ humidity at $37^{\circ} \mathrm{C}$ for a night and the color formed was measured at $550 \mathrm{~nm}$ wavelength by the microplate reader (BioTek Instruments, USA).

Measurement of Cell surface Grp78 levels: Cell surface Grp78 quantity was studied with the Cell ELISA method. ELISA method was designed by us. 96 well tissue culture plate 5,000 cells/200 $\mu 1$ /well were plated and they were kept waiting in a drying oven with $5 \% \mathrm{CO}_{2}$ and $95 \%$ humidity at $37^{\circ} \mathrm{C}$ for 24 hours. The drugs in every group were applied separately to the cells after 24 hours. After 24 hours within the medicated medium, all the wells were washed out with PBS and the cells were fixed with $100 \mu \mathrm{l}$ $3.7 \%$ formaldehyde and incubated for 20 minutes at room temperature. Then the wells were washed out with PBS, a blocking buffer including $1 \%$ bovine serum albumin was added and incubated for an hour at room temperature. The wells were washed again with PBS and Grp78 rabbit polyclonal IgG primary antibodies (Santa Cruz, USA) were added. After washing with PBS, anti-Rabbit IgG polyclonal secondary antibodies related to horseradish peroxides (Sigma Aldrich, USA) were added and incubated. Tetramethylbenzidine was added to the wells and it was read at $655 \mathrm{~nm}$ by the micro plate reader (BioTek Instruments, USA).

Staining with Janus Green: Staining with Janus Green for the normalization of every well of the plate was performed by modifying the method of Raspotnig $^{27}$ et al. After reading at $655 \mathrm{~nm}$, the plate was washed with distilled water. Janus Green B (pH: 7.17.2 , Acros Organics, Belgium) was added and it was incubated at $20-25^{\circ} \mathrm{C}$ for 5 minutes. Then the stain was removed and the plate was washed with distilled water. $0.5 \mathrm{~N} \mathrm{HCl}$ was added, incubated at $20-25^{\circ} \mathrm{C}$ for 10 minutes and the absorbance was measured at $615 \mathrm{~nm}$. The values measured at $655 \mathrm{~nm}$ were compared with the values measured at $615 \mathrm{~nm}$ and normalization was performed per well.
Statistical analysis: All the data were analyzed using the statistical software SPSS 15.0 (SPSS, Chicago, IL). For the group comparisons, Mann-Whitney $U$ test was used. The values were given as median, minimum value and maximum value. The significance level was accepted as $\alpha=0.05$.

\section{RESULTS}

HepG2 cell quantity to be planted at every well of the plate was determined as 5,000 cells/well (Graphic 1).

2-DG was used in the study in order to provide hypoglycemic and hypoxic environment in which the cells are present in the center of cancer in 7 groups.

Different treatment applied for every group affected the cell viability disparately. In this study, MTT assay was used to follow up the cell viability. In the cell viability test performed by MTT; the viability of the control group was accepted as $\% 100$ and the viability of the other groups was given by comparing them with the control group. When we look at the viability in 2.5, 5 and $10 \mathrm{mM}$ ASA given alone groups, the maximum was in the $2.5 \mathrm{mM}$ group, and the minimum was in the $10 \mathrm{mM}$ group (Graphic 2).

In the groups where 2-DG and ASA were combined, cell death was quite much than the groups where only ASA was given. When viability was $\% 81.62$, $77.76 \%$ and $\% 68.28$ in the $2.5,5$ and $10 \mathrm{mM}$ ASA group respectively; viability was $22.47 \%, 19.82 \%$ and $15.53 \%$ in the 2-DG+2.5 mM ASA, 2-DG+5 $\mathrm{mM}$ ASA and 2-DG+10 mM ASA group respectively. When the cell viability in etoposide group was $84.49 \%$, the cell viability in 2-DG+etoposide group was $75.40 \%$. This shows us that the 2-DG increase the effect of both ASA and etoposide. When 2.5, 5 and $10 \mathrm{mM}$ ASA was added to the 2-DG+etoposide group; the cell viability was $69.18 \%, 64.38 \%$ and $15.24 \%$ respectively. This means that ASA increase its effect on etoposide both in the medium with 2-DG and without 2-DG (Graphic 2).

When the cell-surface Grp78 quantity in the $2.5 \mathrm{mM}$ ASA and $5 \mathrm{mM}$ ASA groups are compared with the control group, they didn't show any significant changes $(p=0.126$ and $p=0.672$, respectively), but the quantity in $10 \mathrm{mM}$ ASA group is compared with the control group, it was found significantly high $(\mathrm{p}=$ 0.035 ). The quantity in the etoposide alone given group was significantly decreased $(\mathrm{p}=0.044)$ (Table 1$)$. 


\begin{tabular}{|c|c|c|c|c|c|}
\hline Groups & $\begin{array}{l}\text { Control } \\
(n=8)\end{array}$ & $\begin{array}{l}\text { Etoposide } \\
(n=8)\end{array}$ & $\begin{array}{l}2.5 \text { mM ASA } \\
(n=8)\end{array}$ & $\begin{array}{l}5 \text { mM ASA } \\
(n=8)\end{array}$ & $\begin{array}{l}10 \text { mM ASA } \\
(n=8)\end{array}$ \\
\hline Cell-surface Grp78 & $\begin{array}{l}0.26 \\
(0.21-0.35)\end{array}$ & $\begin{array}{l}0.215 \\
(0.18-0.29)^{\star *}\end{array}$ & $\begin{array}{l}0.205 \\
(0.18-0.34)^{*}\end{array}$ & $\begin{array}{l}0.27 \\
(0.23-0.34)^{\star}\end{array}$ & $\begin{array}{l}0.31 \\
(0.26-0.43)^{\star *}\end{array}$ \\
\hline \multicolumn{6}{|c|}{ 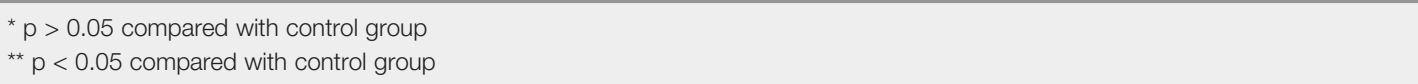 } \\
\hline \multicolumn{6}{|c|}{ ASA= Acetic salicylic acid; $n=$ number of patients; Grp= glucose regulated protein } \\
\hline
\end{tabular}

When compared with 2-DG+etoposide group, the cell surface Grp78 levels of 2-DG+etoposide $+5 \mathrm{mM}$ ASA and 2-DG+etoposide+10 mM ASA groups were found significantly higher $(\mathrm{p}=0.019$ and $\mathrm{p}=0.023$, respectively). However, no significant change was recorded in the 2-DG + etoposide $+2.5 \mathrm{mM}$ ASA group $(\mathrm{p}=0.170)$. This shows that when the given ASA dose increases, cell-surface Grp78 quantity also increases (Table 2).

\section{DISCUSSION}

In order to determine the effects of the drugs on the cell, first of all the cells should be planted in the wells with equal quantities. Approximately 24 hours should be waited in order to have the cells get fixed and grew and then the material of which the effect will be tried should be added. After the cells are planted and after they pass through the fixation and exponential growth stages, they reach to the plateau phase. At this point the cells fill the surface of the culture plate completely and they start to get off from the surface and die because of the insufficiency of medium and the area. The best cell quantity for the drug application to be performed 24 hours after the cells are fixed, is determined according to the initial cell quantity which has reached to the exponential growth stage after 24 hours. When the literature is reviewed, it will be seen that the quantity of HepG 2 cell used in the in vitro studies are different such as $10^{4}$ cells/well ${ }^{28}, 8 \times 10^{3}$ cells/well. ${ }^{29}$ For the determination of the cell quantity, our method is far away from subjectivity and in this study, $5 \times 10^{3}$ cells/well cells are used.

There are some regions in the structure of the solid tumors where glucose deprivation and hypoxia are seen because of the insufficiencies in vascularization. Hypoxia and hypoglycemia causes acidosis and changes in the cell metabolism and the metabolism of these regions are different from the metabolism of other regions and these areas are mostly take place in the center of the tumor. These areas in the center of the tumor form the most aggressive part and in order to provide a complete curing; these areas in the center should be deactivated..$^{30}$ In our study, 2-DG was used to stimulate this glucose deprive and hypoxic areas in the tumor structure. As seen in the MTT assay, when the viability in the etoposide group is high,

\begin{tabular}{|c|c|c|c|c|}
\hline Groups & $\begin{array}{l}\text { 2-DG + etoposide } \\
(n=8)\end{array}$ & $\begin{array}{l}\text { 2-DG + etoposide } \\
+2.5 \mathrm{mM} \text { ASA }(n=8)\end{array}$ & $\begin{array}{l}\text { 2-DG + etoposide } \\
+5 \mathrm{mM} \text { ASA }(n=8)\end{array}$ & $\begin{array}{l}\text { 2-DG + etoposide } \\
+10 \mathrm{mM} \text { ASA }(n=8)\end{array}$ \\
\hline Cell-surface Grp78 & $\begin{array}{l}0.295 \\
(0.23-0.40)\end{array}$ & $\begin{array}{l}0.345 \\
(0.26-0.40)^{\star}\end{array}$ & $\begin{array}{l}0.36 \\
(0.30-0.44)^{\star \star}\end{array}$ & $\begin{array}{l}0.35 \\
(0.29-0.46)^{\star *}\end{array}$ \\
\hline
\end{tabular}




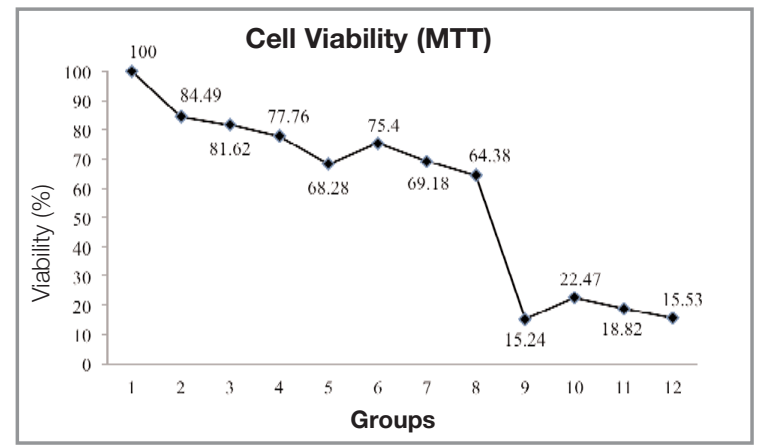

Graphic 2. Showing the cell viability in the groups with 3-(4, 5dimethylthiazol-2-yl)-2,5 diphenyl tetrazolium bromide (MTT) Assay. The control group was accepted as $\% 100$ and the decreases in the other groups were given by comparing with the control group. (1) Control group, (2) $0.5 \mu \mathrm{g} / \mathrm{ml}$ etoposide group, (3) 2.5 $\mathrm{mM}$ acetyl salicylic acid group, (4) $5 \mathrm{mM}$ acetyl salicylic acid group, (5) $10 \mathrm{mM}$ acetyl salicylic acid group, (6) $10 \mathrm{mM}$ 2-deoxyglucose $+0.5 \mathrm{\mu g} / \mathrm{ml}$ etoposide group, (7) $10 \mathrm{mM}$ 2-deoxyglucose $+0.5 \mu \mathrm{g} / \mathrm{ml}$ etoposide $+2.5 \mathrm{mM}$ acetyl salicylic acid group, (8) 10 $\mathrm{mM} 2$-deoxyglucose $+0.5 \mu \mathrm{g} / \mathrm{ml}$ etoposide $+5 \mathrm{mM}$ acetyl salicylic acid group, (9) $10 \mathrm{mM}$ 2-deoxyglucose $+0.5 \mu \mathrm{g} / \mathrm{ml}$ etoposide + 10 mM acetyl salicylic acid group, (10) 10 mM 2-deoxyglucose + $2.5 \mathrm{mM}$ acetyl salicylic acid group, (11) $10 \mathrm{mM}$ 2-deoxyglucose + 5 mM acetyl salicylic acid group, (12) 10 mM 2-deoxyglucose + $10 \mathrm{mM}$ acetyl salicylic acid group.

the viability in 2-DG+etoposide group was about $75.40 \%$. These results show that 2-DG decreases the viability on the cells even a little.

Although the mechanism of antitumor activity of ASA is not known definitely, prostaglandin endoperoxide $\mathrm{H}$ synthases-2 (PGHS-2, COX-2) inhibition which is the target of non-steroidal anti-inflammatory drugs has an important role in reviewing this effect. Salicylic acid, the metabolite of ASA, causes depression in COX-2 messenger RNA (mRNA) and protein expression in the endothelial cells and fibroblasts with 10-4-10-5 mol/L concentrations. ${ }^{31}$ If ASA is at higher doses, it induces apoptosis with the mechanisms different than the COX inhibition. For example, it adjusts proapoptotic gen PAWR ${ }^{32}$ and antiapoptopic gen BCL2L1..$^{33}$ Also, they cause the increase of the protein quantity in the DNA repairing mechanism and provide the renovation of the mismatches created in DNA. ${ }^{34}$ Together, inhibition of the phenol sulphotransferase, which is the carcinogen activator of ASA, can also be important in terms of the prevention of tumor formation..$^{35}$ Salicylates also provide $\mathrm{p} 38$ mitogen-activated protein kinase activa- tion and stimulate apoptosis..$^{36-38}$ As can be seen, ASA induces apoptosis by using different mechanisms and shows an antitumor effect. In our study, ASA shows an antitumor activity on the HepG2 cells. Viability in the $2.5 \mathrm{mM}, 5 \mathrm{mM}$ and $10 \mathrm{mM}$ ASA groups is determined as $81.6 \%, 77.8 \%$ and $68.3 \%$ respectively. When ASA is combined with 2-DG, it has the same effect on the HepG2 cells. Viability in the 2-DG+2.5 $\mathrm{mM}$ ASA, 2-DG+5 mM ASA and 2-DG+10 mM ASA groups is determined as $22.47 \%, 19.82 \%$ and $15.53 \%$ respectively (Graphic 2). These results present that ASA shows antitumor activity both in the center and in the peripheral area of the tumor and when the dose increases, the viability decreases as inversely proportional. ASA may have used the above mentioned mechanisms when providing these effects.

There are some studies showing that ASA can be beneficiary in the hepatocellular cancer treatment. For example, in the study performed by $\mathrm{Abiru}^{39}$ et al., HepG2 invasion skill induced by the hepatocyte growth factor (HGF) and matrix metalloproteinase (MMP) 9 activity decreases when ASA is given. The cell line used in our study is the HepG2 cell line having the hepatocellular carcinoma cell line. As can be seen in Graphic 2, ASA caused reduction in the HepG2 cell line viability. This also shows that ASA can be useful in the treatment of liver cancer.

In the study performed with the Chinese hamster ovary (CHO) and T24/83 human bladder carcinoma cell lines; there is correlation between the Grp78 over-expression and the etoposide resistance. Exposing the cells to etoposide for a long time, it causes the Grp78 levels increase. Applying etoposide to the media, it causes an increase in the caspase-7 levels and has the cell to go to apoptosis however Grp78 over-expression prevents apoptosis and as a result of this, resistance against the etoposide treatment occurs. In the structure of Grp78; ATP binding/hydrolysis activity is present and the interaction of this region with caspase-7 is very important in terms of affecting apoptosis. ${ }^{2,40}$ When the viability of the cells is observed in the MTT test; the viability in $10 \mathrm{mM}$ 2-deoxyglucose $+0.5 \mu \mathrm{g} / \mathrm{ml}$ etoposide group was $75.4 \%$, additional to these drugs, the given 2.5 $\mathrm{mM}, 5 \mathrm{mM}$ and $10 \mathrm{mM}$ ASA doses are approximately $69.2 \%, 64.4 \%, 15.2 \%$ respectively. ASA used in our study, leads the ATPaz inhibition, inhibits the 
ATPaz region in the structure of Grp78 and can prevent the interaction of Grp78 with caspase-7. This inhibition made by ASA increases the apoptosis, performing via caspase-7 and can cause cell deaths.

In our study, the cell-surface Grp78 levels, not intracellular Grp78 levels, are measured. Cell surface Grp78 levels in the etoposide group decreased significantly but it has increased significantly in the 10 mM ASA group. When compared to the 2-DG+etoposide group, cell surface Grp78 levels are found significantly high in the 2-DG+etoposide+5 $\mathrm{mM}$ ASA and 2-DG+etoposide $+10 \mathrm{mM}$ ASA groups. When the literature is reviewed, Grp78 over-expression prevents damages in ER stress exposed to normal tissues and causes cancer progression and drug resistance in the neoplastic cells. ${ }^{41}$ However according to our results, as being different from Grp78, the cell-surface Grp78 levels and cell viability increase inversely proportional. This increase in the Cell-surface Grp78 levels can be inductive in the realization of apoptosis and further studies can be tried with new treatment options in which the cell-surface Grp78 is aimed.

The purpose is to convert the monomeric form which is the active form of (-) - Epigallocatechin gallate (EGCG) Grp78 into inactive dimeric or oligomeric form. ${ }^{42}$ As EGCG, ASA brings the monomeric form of Grp78 into dimeric and oligomeric form and could inhibit the effect of Grp78 and thus the cell deaths could be increased. ASA and sodium salicylate are connected to Bip/GRP78/PERK complex in ER and can cause the auto activation of PERK and the phosphorilation of eIF2- $\alpha$. It is in turn causes cell deaths via apoptosis. ${ }^{43}$

Studies for the relationship of ASA with cancer are still in progress. A part of the results shows that positive results are obtained in cancer treatment but on the other hand, another part shows that they are not useful in the treatment. In our results, it is shown that ASA can play a positive role in the treatment of cancer and cell surface Grp78 can have a role in this effect. However, more studies are needed to see exact results in this field.

\section{REFERENCES}

1. Ma Y, Hendershot LM. ER chaperone functions during normal and stress conditions. J Chem Neuroanat 28: 51-65, 2004
2. Reddy RK, Mao C, Baumeister P, et al. Endoplasmic reticulum chaperone protein GRP78 protects cells from apoptosis induced by topoisomerase inhibitors: role of ATP binding site in suppression of caspase-7 activation. J Biol Chem 278: 20915-20924, 2003.

3. Sun FC, Wei S, Li CW, et al. Localization of GRP78 to mitochondria under the unfolded protein response. Biochem J 396: 31-39, 2006.

4. Ni M, Zhou H, Wey S, et al. Regulation of PERK signaling and leukemic cell survival by a novel cytosolic isoform of the UPR regulator GRP78/BiP. PLoS One 4: e6868, 2009.

5. Berger CL, Dong Z, Hanlon D, et al. A lymphocyte cell surface heat shock protein homologous to the endoplasmic reticulum chaperone, immunoglobulin heavy chain binding protein BIP. Int J Cancer 1997 71: 10771085, 1997.

6. Kim I, Xu W, Reed JC. Cell death and endoplasmic reticulum stress: disease relevance and therapeutic opportunities. Nat Rev Drug Discov 7: 1013-30, 2008.

7. Rutkowski DT, Kaufman RJ. A trip to the ER: coping with stress. Trends Cell Biol 14: 20-28, 2004.

8. Lee AS. The ER chaperone and signaling regulator GRP78/BiP as a monitor of endoplasmic reticulum stress. Methods 35: 373-81, 2005.

9. Liu Y, Steiniger SC, Kim Y, et al. Mechanistic studies of a peptidic GRP78 ligand for cancer cell-specific drug delivery. Mol Pharm 4: 435-447, 2007.

10. Misra UK, Deedwania R, Pizzo SV. Binding of activated alpha2-macroglobulin to its cell surface receptor GRP78 in 1-LN prostate cancer cells regulates PAK-2dependent activation of LIMK. J Biol Chem 280: 26278-26286, 2005.

11. Misra UK, Deedwania R, Pizzo SV. Activation and cross-talk between Akt, NF-kappa B, and unfolded protein response signaling in 1-LN prostate cancer cells consequent to ligation of cell surface-associated GRP78. Journal of Biological Chemistry 281: 1369413707, 2006.

12. Kelber JA, Panopoulos AD, Shani G, et al. Blockade of Cripto binding to cell surface GRP78 inhibits oncogenic Cripto signaling via MAPK/PI3K and Smad2/3 pathways. Oncogene 28: 2324-2336, 2009.

13. Burikhanov R, Zhao YM, Goswami A, et al. The Tumor Suppressor Par-4 Activates an Extrinsic Pathway for Apoptosis. Cell 138: 377-388, 2009.

14. Bhattacharjee G, Ahamed J, Pedersen B, et al. Regulation of tissue factor--mediated initiation of the coagulation cascade by cell surface grp78. Arterioscler Thromb Vasc Biol 25: 1737-1743, 2005.

15. Katanasaka $\mathrm{Y}$, Ishii $\mathrm{T}$, Asai $\mathrm{T}$, et al. Cancer antineovascular therapy with liposome drug delivery systems targeted to BiP/GRP78. Int J Cancer 127: 2685-2698, 2010.

16. Morris JA, Dorner AJ, Edwards CA, et al. Immunoglobulin binding protein (BiP) function is required to protect cells from endoplasmic reticulum stress but is not required for the secretion of selective proteins. Journal of Biological Chemistry 272: 4327-4334, 1997. 
17. Gasic GJ, Gasic TB, Murphy S. Anti-metastatic effect of aspirin. Lancet 2: 932-933, 1972.

18. Kune GA, Kune S, Watson LF. Colorectal cancer risk, chronic illnesses, operations, and medications: case control results from the Melbourne Colorectal Cancer Study. Cancer Res 48: 4399-4404, 1988.

19. Vane JR. Inhibition of prostaglandin synthesis as a mechanism of action for aspirin-like drugs. Nat New Biol 231: 232-235, 1971.

20. Jaffe BM. Prostaglandins and cancer: an update. Prostaglandins 6: 453-461, 1974.

21. Bennett A, Del Tacca M. Proceedings: Prostaglandins in human colonic carcinoma. Gut 16: 409, 1975.

22. Mahdi JG, Alkarrawi MA, Mahdi AJ, et al. Calcium salicylate-mediated apoptosis in human HT-1080 fibrosarcoma cells. Cell Prolif 39: 249-260, 2006.

23. Futakuchi M, Ogawa K, Sano M, et al. Suppression of lung metastasis by aspirin but not indomethacin in an in vivo model of chemically induced hepatocellular carcinoma. Jpn J Cancer Res 93: 1175-1181, 2002.

24. Yuan JN, Chao Y, Lee WP, et al. Chemotherapy with etoposide, doxorubicin, cisplatin, 5-fluorouracil, and leucovorin for patients with advanced hepatocellular carcinoma. Med Oncol 25: 201-206, 2008.

25. Wilstermann AM, Bender RP, Godfrey M, et al. Topoisomerase II - drug interaction domains: identification of substituents on etoposide that interact with the enzyme. Biochemistry 46: 8217-8225, 2007.

26. Oh SY, Sohn YW, Park JW, et al. Selective cell death of oncogenic Akt-transduced brain cancer cells by etoposide through reactive oxygen species mediated damage. Mol Cancer Ther 6: 2178-2187, 2007.

27. Raspotnig G, Fauler G, Jantscher A, et al. Colorimetric determination of cell numbers by Janus green staining. Anal Biochem 275: 74-83, 1999.

28. Zeng $X$, Wang $Y$, Qiu Q, et al. Bioactive phenolics from the fruits of Livistona chinensis. Fitoterapia 83: 104-109, 2012.

29. Yang $X R$, Wang $Y Y$, La KK, et al. Inhibitory effects of cocoa tea (Camellia ptilophylla) in human hepatocellular carcinoma HepG2 in vitro and in vivo through apoptosis. J Nutr Biochem 23: 1051-1057, 2012.

30. Brown JM, Giaccia AJ. The unique physiology of solid tumors: opportunities (and problems) for cancer therapy. Cancer Res 58: 1408-1416, 1998.

31. Xu XM, Sansores-Garcia L, Chen XM, et al. Suppression of inducible cyclooxygenase 2 gene transcription by aspirin and sodium salicylate. Proc Natl Acad Sci USA 96: 5292-5297, 1999.

32. Zhang Z, DuBois RN. Par-4, a proapoptotic gene, is regulated by NSAIDs in human colon carcinoma cells. Gastroenterology 118: 1012-1017, 2000.

33. Zhang L, Yu J, Park BH, et al. Role of BAX in the apoptotic response to anticancer agents. Science 290: 989-992, 2000.
34. Goel A, Chang DK, Ricciardiello L, et al. A novel mechanism for aspirin-mediated growth inhibition of human colon cancer cells. Clin Cancer Res 9: 383-390, 2003.

35. Harris RE, Beebe-Donk J, Doss H, Burr Doss D. Aspirin, ibuprofen, and other non-steroidal anti-inflammatory drugs in cancer prevention: a critical review of non-selective COX-2 blockade (review). Oncol Rep 13: 559-583, 2005.

36. Kopp E, Ghosh S. Inhibition of NF-kappa B by sodium salicylate and aspirin. Science 265: 956-959, 1994.

37. Pierce JW, Read MA, Ding H, et al. Salicylates inhibit I kappa B-alpha phosphorylation, endothelial-leukocyte adhesion molecule expression, and neutrophil transmigration. J Immunol 156: 3961-3969, 1996.

38. Schwenger P, Bellosta P, Vietor I, et al. Sodium salicylate induces apoptosis via p38 mitogen-activated protein kinase but inhibits tumor necrosis factor-induced C-Jun N-terminal kinase/stress-activated protein kinase activation. Proc Natl Acad Sci USA 94: 28692873, 1997.

39. Abiru S, Nakao K, Ichikawa T, et al. Aspirin and NS398 inhibit hepatocyte growth factor-induced invasiveness of human hepatoma cells. Hepatology 35 : 1117-1124, 2002.

40. Hendershot LM, Wei JY, Gaut JR, et al. In vivo expression of mammalian BiP ATPase mutants causes disruption of the endoplasmic reticulum. Mol Biol Cell 6: 283-296, 1995.

41. Lee AS. The glucose-regulated proteins: stress induction and clinical applications. Trends Biochem Sci 26: 504-510, 2001.

42. Ermakova SP, Kang BS, Choi BY, et al. (-)-Epigallocatechin gallate overcomes resistance to etoposideinduced cell death by targeting the molecular chaperone glucose-regulated protein 78. Cancer Res 66: 9260-9269, 2006.

43. Silva AM, Wang D, Komar AA, et al. Salicylates trigger protein synthesis inhibition in a protein kinase R-like endoplasmic reticulum kinase-dependent manner. J Biol Chem 282: 10164-10171, 2007.

\section{Correspondence:}

Dr. Hasan ALAÇAM

Ondokuz Mayıs Üniversitesi Tıp Fakültesi

Tıbbi Biyokimya Anabilim Dalı

Kurupelit, 55139, Samsun / TURKEY

e-mail: hasanalacam@hotmail.com

Tel: (+90.362) 31219 19/3468

Fax: (+90.362) 4576041 